NBSIR 83-2733

\title{
Characterization of Controlled Release Dynamics and Identification of Species Released From OMP Impregnated Wood Pilings
}

U.S. DEPARTMENT OF COMMERCE

National Bureau of Standards

National Measurement Laboratory

Center for Materials Science

Inorganic Materials Division

Chemical and Biodegradation Processes Group

Washington, DC 20234

July 1983

Prepared for

The Naval Civil Engineering Laboratory

Code L-52

Port Heneme, CA 93043

.456

83-2733

1033

C.2 
NBSIR 83-2733

CHARACTERIZATION OF CONTROLLED

RELEASE DYNAMICS AND

IDENTIFICATION OF SPECIES RELEASED

FROM OMP IMPREGNATED WOOD

PILINGS

W. R. Blair, E. J. Parks, and F. E. Brinckman

U.S. DEPARTMENT OF COMMERCE

National Bureau of Standards

National Measurement Laboratory

Center for Materials Science

Inorganic Materials Division

Chemical and Biodegradation Processes Group

Washington, DC 20234

July 1983

Prepared for

The Naval Civil Engineering Laboratory

Code L-52

Port Heneme, CA 93043

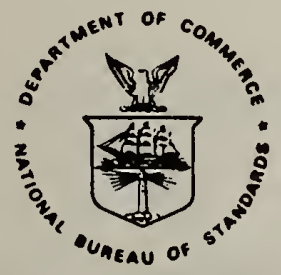

U.S. DEPARTMENT OF COMMERCE, Malcolm Baldrige, Secretary NATIONAL BUREAU OF STANDARDS, Ernest Ambler, Director 



\section{CHARACTERIZATION OF CONTROLLED RELEASE DYNAMICS AND IDENTIFICATION OF SPECIES RELEASED FROM OMP IMPREGNATED WOOD PILINGS}

\section{W. R. Blair, E. J. Parks, and F. E. Brinckman Inorganic Materials Division National Bureau of Standards Washington, DC 20234}

ABSTRACT

Tin containing organometallic polymers (OMP) are becoming an increasingly important class of compounds finding application in marine environments as antifouling and preservative agents. To provide accurate estimates of service life and reliability in service, new analytical methods are needed for the identification and measurement of the toxic species being delivered by the OMP. This report is concerned with the following: identification of parent tin species; identification of species released from OMP impregnated wood pilings; and preliminary determination of the rate of tin release from impregnated pilings. Additionally, the influence of microbiological activities on the release process is considered in assessing the effectiveness and ultimate fate of the toxic species responsible for the antifouling and preservative properties of the OMP formulation. Data from release rate measurement experiments are presented, along with chromatograms providing speciation data on parent tin compounds in the pilings and released compounds in the aqueous phase. Discussion of areas for continued research are presented.

KEY WORDS: atomic absorption spectrophotometry; cation exchange chromatography; high pressure liquid chromatography; in situ polymerization; controlled release; organometallic polymers; size exclusion chromatography; tributyltin 


\section{Introduction}

The United States Navy is investigating the use of tin containing organometallic polymer (OMP) formulations as antifouling agents and wood preservatives. The OMPs are prepared by copolymerization of two or more monomeric species, typically esters of methacrylic acid, e.g. methylmethacrylate (MMA) and tributyltin methacrylate (TBTM). Coated on ship hulls, copolymers of MMA and TBTM provide years of antifouling protection in the marine service environment (1). In the case of wood pilings, the respective OMP monomers impregnate the wood and are believed to undergo reactions, including polymerization, in situ (2).

Questions and problems arise from the perspectives of longevity in service and environmental impact. What is the chemistry of reactions that occur in wood pilings? How rapidly do the wood pilings lose toxic tin-bearing moieties? What chemical species actually migrate into the environment? What is their probable effect on marine organisms in the immediate vicinity of the pilings? How long will the OMPs remain effective? The leaching mechanism, not yet fully understood, depends on mariy factors such as: the extent of polymerization in situ; the nature of surface reactions between wood components and the tin-bearing moieties; and the chemical reactions involved in transfering the tin species from the wood-polymer matrix into the aqueous environment. Samasekharen and Subramanian state, "The identification of the chemical species will enable one to evaluate the change in bulk characteristics of the coatings as leaching progresses. The knowledge of this chemical moiety is a prerequisite for a meaningful study of the rate of leaching and the mechanism of release." (3) 
Our laboratory, at the request of the Naval Civil Engineering Laboratory (NCEL), initiated an investigation into slow-release processes under controlled conditions. We were provided with two debarked southern yellow pine wood posts ( $31 / 2$ feet long and approximately 4 inches in diameter). One post had been impregnated with a TBTM and MMA mixture (Piling No. 3-1), and one impregnated with TBTM and glycidyl methacrylate (GMA), (Piling No. 4-5). This report summarizes preliminary research initated in FY82 to investigate the performance of these OMP impregnated wood pilings in a simulated marine environment. Specific activities include:

-Development of methods for the measurement of total tin release from OMP impregnated wood pilings into artificial estuarine water -Speciation of aqueous tin bearing moieties released from OMP impregnated pilings

-Size exclusion chromatography (SEC) of tetrahydrofuran (THF) extractable components of the material impregnating the wood

-Microbiological monitoring of aquatic bacterial cell numbers prior to and during release of organotin species

-Assessment of most profitable areas for continued research

\section{Experimental}

2.1 Vessels, Solutions, and Sample Preparation

In two sets of experiments described below, the rates of total tin release (leach rate) were measured for sample specimens taken from pilings 4-5 and 3-1. The pilings were cut with a hand saw having a 
steel 10 point cross-cut blade with teeth hardened by heat induction, into smaller sections for use as test specimens. Pyrex glass jars were used as containers for water and piling specimens. The jars were cleaned prior to use, first with warm water and soap, then by leaching for several days with aqueous $10 \% \mathrm{HNO}_{3}$. Following acid leaching, the jars were rinsed 4 to 5 times with deionized water (resistance of 15 to $18 \mathrm{M} / \mathrm{cm}$, Culligan Aqua Suma 36, Culligan Corporation, Northbrook, IL). The following salts, in grams per liter, were added to deionized water: $\mathrm{NaCl}, 24.0 ; \mathrm{MgCl}_{2} \cdot 6 \mathrm{H}_{2} \mathrm{O}, 5.0 ; \mathrm{MgSO}_{4} \cdot 7 \mathrm{H}_{2} 0,7.0 ; \mathrm{KCl}, 0.7$, producing an artificial estuarine water with a total salt content of 15.24 parts per thousand. All salts used in preparation of the artificial estuarine water were of reagent grade. The formula for the artificial estuarine water was obtained from a personal communication with the Department of Microbiology at the University of Maryland.

\subsection{Piling Release Ratè Determination}

Two separate leaching experiments were performed. The first was a small scale test conducted primarily to determine if there would be a large initial release of tin soon after the pilings were exposed to water. The second experiment, with a ratio of wood area to water volume of approximately half that of experiment 1 (see table 1), was considered better suited for resolution of both the initial rise in tin concentration as leaching started and long term monitoring of the tin concentration. Except for the differences in water volume and size of piling specimens used, the two leach rate experiments were performed identically. 
Piling Specimen Data

Experiment No. 1

Diameter:

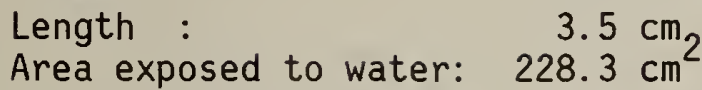

$11.4 \mathrm{~cm}$

Pyrex jar water volume: $2.0 \mathrm{~L}$

Ratio, wood area/water volume: $228.3 \mathrm{~cm}^{2} / 2.0 \mathrm{~L}=114.15 \mathrm{~cm}^{2} / \mathrm{L}$

Experiment No. 2

Diameter:

Length : $\quad 45.0 \mathrm{~cm}_{2}$ overal1, $22.0 \mathrm{~cm}$ immersed

Area exposed to water: $1000.3 \mathrm{~cm}^{2}$

Pyrex jar water volume: $16.0 \mathrm{~L}$

Ratio, wood area/water volume: $1000.3 \mathrm{~cm}^{2} / 16.0 \mathrm{~L}=62.5 \mathrm{~cm}^{2} / \mathrm{L}$

In the initial release rate measurement experiment (experiment 1), sections of the pilings $3.5 \mathrm{~cm}$ thick were allowed to float in Pyrex glass jars containing 2 liters of artificial estuarine water. The piling sections rapidly absorbed water and settled so that all but their upper surface was exposed to the water, presenting a total area of $228.3 \mathrm{~cm}^{2}$ to the water. In the second experiment, the piling sections were suspended in the jars by clamps attached to the jar covers.

Twenty-two centimeters of their length was exposed to the water, presenting a total surface area of $1000.3 \mathrm{~cm}^{2}$ to the water.

The water was stirred constantiy by magnetically driven teflon (PTFE) covered stirring bars rotating at $650 \mathrm{rpm}$. Water samples of $1.0 \mathrm{~mL}$ volume were withdrawn periodically through small bore teflon tubes (1.0 mm I.D.) connected to plastic syringes. Teflon (PTFE) tubing and a syringe for sample withdrawal was provided for each jar. Samples were dispensed directly into polystyrene cups which fit into an auto sampler on a graphite furnace atomic absorption spectrophotometer (GFAA) (Model 
460 Perkin Elmer, Norwalk, CT). GFAA determinations for total tin were started immediately after the jars were sampled. Sampling continued for 19 days and 35 days respectively, in experiments 1 and 2 . Table 2 lists the GFAA parameters employed for aqueous sample analyses and for the GFAA when used as a HPLC detector.

Table 2

GFAA Parameters: General

Lamp: Tin Electrodeless discharge, 8 watts

Wavelength: $224.6 \mathrm{~nm}$

Slit width: $0.7 \mathrm{~nm}$

Integration time: 8.0 seconds

D2 Background correction on at all times

Graphite Furnace: Aqueous samples

Drying, $\quad 50 \mathrm{sec}$ at $125{ }^{\circ} \mathrm{C}$

Charring, $\quad 30 \mathrm{sec}$ at $150{ }^{\circ} \mathrm{C}$

Atomization, $6 \mathrm{sec}$ at $2700{ }^{\circ} \mathrm{C}$

GFAA Parameters: HPLC Detector

Parameters as above with the following exceptions:

Graphite Furnace: SCX Chromatography

Drying, $\quad 10 \mathrm{sec}$ at $90^{\circ} \mathrm{C}$

Charring, $10 \mathrm{sec}$ at $90^{\circ} \mathrm{C}$

Atomization, $6 \mathrm{sec}$ at $2700{ }^{\circ} \mathrm{C}$

Graphite Furnace: SEC Chromatography

Drying, $\quad 10 \mathrm{sec}$ at $100{ }^{\circ} \mathrm{C}$

Charring, $\quad 10 \mathrm{sec}$ at $200{ }^{\circ} \mathrm{C}$

Atomization, $10 \mathrm{sec}$ at $2700{ }^{\circ} \mathrm{C}$

Each time total tin determinations were made, the GFAA was calibrated with freshly prepared tributyltin chloride standards. Calibration curves typically contained 4 to 5 points with 4 to 6 replicates run at each point.

For the 20 calibrations performed during the course of experiment 2 correlation coefficients of 0.967 to 0.998 were obtained, with an average value and standard deviation of $0.992 \pm 0.008$. 
3. Chemical Speciation of Materials Released from Piling and Solvent Extracts

\subsection{Tin Speciation Methodology}

Chemical speciation of the tin compounds in the aqueous piling leachates and THF extracts of the OMP impregnated pilings was performed by coupled liquid chromatography-atomic absorption spectrophotometric (HPLC-GFAA) methods previously developed in our laboratory $(4,5)$. In figure 1 is given a block diagram of the HPLC-GFAA analysis system. Samples are injected into flowing eluents at the sample injection valve. Analytes separated on the chromatographic column are detected by one or more of the following on-line detectors: ultraviolet absorption, differential refractive index, or element specific GFAA. The same HPLC-GFAA apparatus, with the appropriate analytical columns and solvents, was used for both cation exchange chromatography (SCX) for the speciation of tin-bearing moieties. in aqueous solution, and for size exclusion chromatography (SEC) of the THF extracts of the material impregnating the pilings. The application of SCX and SEC chromatography for the characterization of organometallic compounds has been described in detail elsewhere $(6,7)$. Column calibration was performed with polystyrene standard samples of known molecular weight [7]. System parameters for the above analyses are listed in table 3. 


\section{Table 3}

\section{Chromatographic Parameters}

SCX Chromatography

Mobile Phase: Methanol/Water, $70 \% / 30 \%$ with 0.08 M Ammonium Citrate Flow Rate: $0.5 \mathrm{~mL} / \mathrm{min}$ for $15 \mathrm{~min}$, then $1.5 \mathrm{~mL} / \mathrm{min}$ for $10 \mathrm{~min}$

Analytical Column: Partisil PXS 10/25 SCX Whatman, Inc., Clifton, NJ

Detectors: GFAA and UV fixed wavelength at $254 \mathrm{~nm}$

SEC Chromatography

Mobile Phase: THF

Flow Rate: $0.5 \mathrm{~mL} / \mathrm{min}$.

Analytical Column: 1000 A $\mu$ Styragel (one) Waters Assoc., Inc. Milford, MA.

Detectors: GFAA and Differential Refractive Index 


\subsection{Sample Preparation for Chromatography}

For chemical speciation of the tin compounds present in the aqueous solution by SCX chromatography, an extraction of the aqueous solution was performed. Eighteen milliliters of water and $2.0 \mathrm{~mL}$ of chloroform were added to a glass $30 \mathrm{~mL}$ separatory funnel and mechanically shaken for a minimum of 30 minutes. The chloroform fraction was then injected $(250 \mu \mathrm{L})$ into the HPLC-GFAA. Extracts from piling 4-5 were injected directly. Due to higher tin concentrations, extracts from piling 3-1 were diluted 1:1 with chloroform prior to injection. The retention times of authentic tributyltin chloride and dibutyltin chloride, dissolved in chloroform, were determined for comparison with the retention times of peaks present in chromatograms of the leachate water extracts.

To obtain samples for SEC chromatography, pieces of the pilings were placed in round bottom flasks and immersed in THF for 3 days. The flasks were swirled manually from time to time. Twenty microliter volumes of the THF extract solutions were injected into the HPLC-GFAA, followed by injection of discrete volumes of THF containing $1 \%(\mathrm{v} / \mathrm{v})$ of glacial acetic acid to effect desorption of cationic tin-bearing species not otherwise eluted from the column (8). The amount of tin-bearing species recovered in SEC-GFAA was determined by collecting all of the eluent, except that consumed by the GFAA, and comparing its tin content to that of the injected sample. 


\section{3 Biological Monitoring}

No attempt was made to produce or maintain sterile conditions in the release rate measurement experiments. Several factors influenced this decision. In considering the possible methods available for sterilizing the piling sections (dry heat, autoclaving, or toxic gas), no method seemed to eliminate the concern that the sterilization process itself might result in chemical or physical changes in the pilings that would modify either the release mechanism or the species of tin released from the pilings, or both. The length of time the controlled release experiments were to run also presented a problem. Even if sterile conditions were produced at the beginning of the experiment, the size of the piling sections and the containing vessels, and the necessity for frequent sampling over a relatively long period of time would make maintenance of sterile conditions impossible without much more elaborate containment facilities.

Finally, it is reasonable to investigate possible microbial mediation of the release process, as clean surfaces become rapidly colonized by a variety of microbiota following their immersion in sea water (9). Prior to placing the piling test specimens in the water to begin experiment 2 , the bacteria in the containing vessels were counted by epifluorescent microscopy. In this technique, a dye which fluoresces in the presence of DNA is used to make the bacterial cells in the sample visible for counting. At the conclusion of the experiment, the bacterial population was again counted. 
4. Results and Discussion

\subsection{Controlled Release: Total Tin Determination}

The results of GFAA determinations of total tin in the release experiments are shown in figures 2 to 5 . In figures 2 and 3 , the data from experiment 1 are plotted. As mentioned above, experiment 1 was designed primarily to discover if a large amount of tin, perhaps unreacted TBTM monomer on the surface of the piling, would be released rapidly upon exposure of the piling to water. Figures 2 and 3 indicate no rapid, initial release of tin.

The data from experiment 2 are plotted in figures 4 and 5 . Despite the frequent calibrations of the GFAA, the data from both experiments show considerable scatter from point to point. Early in the experiment, this scatter was attributed to surface adsorption of tin to the glass container walls of the containing vessels, but a closer examination of the measurement process revealed that a significant signal interference in the graphite furnace was influencing the total tin determinations.

Total tin levels were determined by direct analysis of the aqueous solutions by GFAA. It was discovered that sodium chloride, present in quantities as low as 0.02 ppt, produced a significant attenuation of the tin signal in the GFAA. A charring step might be included in the GFAA furnace program to help eliminate signal problems produced by components in the sample matrix. Charring temperatures high enough to char off the interfering salts, however, would also be high enough to volatilize organotins from the sample, causing a signal loss of greater magnitude than the suppression originally produced by the salts. 
Because of these problems with signal suppression in direct GFAA analyses of the aqueous solution, the figures presented for experiments 1 and 2 represent the relative change in tin concentration taking place in the containing vessels, not the quantitative total of tin released. Further release studies were postponed at this point, and time was devoted to development of a quantitative method for the measurement of organotin compounds in saline media.

To overcome the signal suppression caused by the salts in the samples an extraction technique was developed in which the aqueous solution is extracted with hexane, then washed with deionized water to remove salts. The extractable organotin concentration is determined by GFAA. Recoveries of tributyltin chloride spiked into saline water are on the order of 90 to 95 per cent. We have found that samples of tributyltin chloride in hexane, are detectable at ppb levels by tin specific GFAA with signal enhancement by ammonium dichromate. The salts present in a saline aqueous medium, or in an unwashed hexane extract, both suppress the tin signal and eliminate the dichromate enhancement effect. Current experimental results indicate that quantitation of $\mathrm{Bu}_{3} \mathrm{SnCl}$ in saline water is feasible at levels below ppb, as well as the ppb quantitation already accomplished. The above extraction method will be employed in all future release rate measurement experiments.

At the conclusion of experiment 2, the above method was applied to determine the total extractable organotin concentrations in the aqueous solutions. The values obtained were used to calculate a release rate for the pilings. These preliminary results are summarized in table 4. The release rate has been expressed as the microgram amount of tin released per square centimeter of wetted piling surface, per day. 
Table 4

\begin{tabular}{lr}
\hline Piling Number & Leach rate \\
\hline $3-1$ & $1.18 \mu \mathrm{g} / \mathrm{cm}^{2} /$ day \\
$4-5$ & $0.31 \mu \mathrm{g} / \mathrm{cm}^{2} /$ day \\
\hline
\end{tabular}

4.2 Speciation of Organotins in Aqueous Solutions and Solvent Extracts

\subsubsection{SCX Chromatography}

The results of SCX-HPLC-GFAA speciation of tin compounds extracted from the aqueous solutions by chloroform are shown in figure 6. A large signal is seen in the chromatograms of piling 3-1 and 4-5 samples at approximately 11 minutes, which corresponds to the retention time of tributyltin cation. Of particular interest, however, is the small signal seen at aproximately 20 minutes, which corresponds to the retention time of dibutyltin cation. The origin of this small peak is of considerable interest, as it could have important implications for the future development of OMPs for antifoulng applications. The dibutyltin peak may be representative of a small amount of impurity present in the TBTM monomer used in forming the OMP in the wood, or possibly a result of microbiological or chemical degradation of the tributyltin. 


\subsubsection{SEC Chromatography}

The results of SEC-HPLC-GFAA analysis of the THF extracts from the pilngs, as received, are shown in figures 7 and 8 . Large differences are apparent in the two figures and in table 4, which summarizes the chromatographic data. In each sample, both the quantity and molecular weight (MW) of the polymerized species show unique characteristics. Polymerization may not predominate in either sample, as evidenced by the relatively large proportions of low MW extractable species seen in the $\Delta R I$ chromatograms of both piling 3-1 and 4-5.

The species desorbed by acetic acid from the crosslinked polystyrene chromatographic packing probably is a tin-bearing cation adsorbed on electron-rich aromatic groups (10). The monomer fraction consists of neutral tin-bearing species (e.g., methacrylic esters). The high MW species probably represents the copolymer formed in situ, although homopolymerization of TBTM cannot be ruled out until the samples are characterized by off-line Fourier transform nuclear magnetic resonance (FT-NMR).

The THF extract of piling 3-1, which used TBTM and MMA precursors, has an extractable polymer content five times greater than that seen in sample 4-5, which used TBTM and GMA precursors. Nevertheless, the total tin content, as determined by washed hexane extract, of the aqueous solution in which piling 3-1 was immersed, exceeded that from piling 4-5 by nearly four times. Thus, the higher quantity of extractable polymer has less correlation with tin release than the choice of co-monomer. This indicates the need for further characterization of 
the impregnated wood fibers; physical examination by microscope, as well as NMR and mass spectroscopic characterization of molecular species.

Table 5

SEC Chromatographic Data

\begin{tabular}{|c|c|c|c|c|c|c|}
\hline \multirow[t]{2}{*}{$\begin{array}{l}\text { Piling } \\
\text { Number }\end{array}$} & \multicolumn{2}{|c|}{$\begin{array}{l}\text { Polymer } \\
\text { Fraction }\end{array}$} & \multicolumn{3}{|c|}{$\begin{array}{c}\text { Fractional Distribution } \\
\text { of Tin }\end{array}$} & \multirow[t]{2}{*}{$\begin{array}{c}\text { Apparent Tin } \\
\text { Recovery }\end{array}$} \\
\hline & $M W$ & MWD & $\begin{array}{c}\text { Polymer } \\
(\%)\end{array}$ & $\begin{array}{c}\text { Monomer } \\
(\%)\end{array}$ & $\begin{array}{c}\text { Adsorbed } \\
\text { Species } \\
(\%)\end{array}$ & \\
\hline $3-1$ & 9350 & 2.29 & 10.1 & 10.8 & 79.1 & 10 \\
\hline $4-5$ & 5280 & 3.88 & 2.1 & 9.9 & 88.0 & 86 \\
\hline
\end{tabular}

$a_{1000}$ to 100,000 daltons

b 100 to 1000 daltons

cdesorbed by acetic acid

\subsection{Biological Activity}

Bacterial species resistant to organotins can be readily isolated from environments stressed by industrial impact (11). The means by which the bacteria acquire their resistance to organotins (and other metals) has not yet been defined. Resistance could be conferred by constitutive or induced intracellular enzymes $(12,13)$. Ability to metabolize or degrade organotins may be aquired by similar routes; resistance and degradation ability could even be transfered together.

Regardless of the method by which the bacteria acquire resistance and or degradation ability, the fact remains that such ability can be readily transferred through a bacterial population. The possibility is very real that if degradation ability exists, the widespread use of organotin antifoulants could produce a selection in the natural community 
for organisms resistant to and able to degrade the organotin toxicants incorporated in the OMPs. The effectiveness of the OMPs might slowly diminish as the natural bacterial population comes to contain more and more resistant/degradative members.

During the course of experiment 2, the bacterial cell count in the containing vessels increased. The data are presented in Table 6 . This increase in cell count is attributed to several factors; an increase in available nutrients and surface area following immersion of the pilings, and minimal effect of tributyltin on a resistant microbial population. Follow-up studies on the ability of this tributyltin resistant population to degrade tributyltin are planned.

Table 6

\begin{tabular}{lcc}
\hline $\begin{array}{l}\text { Piling } \\
\text { Number }\end{array}$ & $\begin{array}{l}\text { Cell Count Prior to } \\
\text { Immersing Pilings }\end{array}$ & $\begin{array}{l}\text { Cell Count 36 days After } \\
\text { Piling Immersion }\end{array}$ \\
\hline $3-1$ & $6.39 \times 10^{5}$ & $2.96 \times 10^{7}$ \\
$4-5$ & $3.91 \times 10^{5}$ & $6.14 \times 10^{6}$ \\
\hline
\end{tabular}

5. Conclusions and Areas for Further Research

The experience gained during the course of this investigation has resulted in a thorough examination of various methods for determining organotin release rates. The results indicate that emphasis must be placed on two areas: measurement of the initial release kinetics to assess environmental impact, especially important if relatively large quantities of tin are released during the initial phases of exposure to the aqueous environment; and long-term monitoring to determine the 
steady-state release rate, allowing predictions of piling longevity to be made. In view of the above recommendations, a new experimental design has been formulated for use in future release rate studies. The closed system, used in this study would still be employed. Water would be circulated around the test specimens. An activated carbon filter would be incorporated into the water circulation system to continually remove organotin from the aqueous solution, preventing a slow increase in tin concentration from influencing the long term release rate. The total tin determinations would be performed using the extraction method described in section 4.1 above, allowing the release rate studies to be conducted in saline water at ocean salinity levels.

The task of evaluating the extent of polymerization of the TBTM and MMA or GMA co-monomers in the wood pilings is quite difficult. Recent evidence (14) suggests that $\mu$ Styragel, the SEC column packing, is capable of cleaving organotin species from polymer chains. This happens if the column is not previously conditioned with an organotin cation and may partially account for the high concentration of adsorbed species seen in Figures 7 and 8 . This question will be reinvestigated with appropriately conditioned SEC columns.

The use of an extraction technique to generate samples for SEC characterization of OMP impregnated wood may result in samples not totally representative of the extent of OMP polymerization in the wood. The GMA co-monomer used in piling 4-5 is believed to form bonds with the cellulose in the wood, making this polymer more resistant to solvent extraction (15). THF extracts of pilings $3-1$ and 4-5 indicate that piling 3-1, which used TBTM and MMA precursors had an extractable polymer content five times greater than piling 4-5, which used the TBTM 
and GMA precursors. However, this may be due to differences in the extractibility or solubility of the respective polymers. The second organotin-release experiment showed that the total tin concentration released from piling 3-1 exceeded that released from piling 4-5 by nearly four times ( $3.8 x)$, lending credance to the suggestion that the TBTM-GMA polymer is either less soluble in THF, or more tightly bonded to the wood.

The Tin Research Institute, in the U.K., has expressed interest in collaborative work concerning the characterization of the OMP in the wood pilings. They have offered to run Mössbauer spectra on samples of OMP impregnated pilings. We hope to begin this collaborative work soon.

\section{Acknowledgments}

The work described in this report was supported by the Naval Civil Engineering Laboratory, Port Hueneme, CA, to whom we extend our thanks. For valued discussion and suggestions, we are indebted to D. Jackson and D. M. Anderson of the David Taylor Naval Ship Research and Development Center, Annapolis, MD. 
7. References

1. W. L. Yeager and V. J.Castelli, Antifouling applications of various tin-containing organometallic polymers, in Organometallic Polymers, C. E. Carrahar, Jr., J. E. Sheats, and C. U. Pittman, Jr., Eds., NY: Academic Press, 1978, 175-180.

2. R. V. Subramanian, J. A. Mendoza and B. K. Garg, Wood preservation by organotin polymers, Holzforschung 35 , 253-259 (1981).

3. K. N. Somasekharan and R. V. Subramanian, Structure, mechanism and reactivity of organotin carboxylate polymers in modification of polymers, ACS Symp. Ser. 121, 165-181 (1980).

4. F. E. Brinckman, W. R. Blair, K. L. Jewett, and W. P. Iverson, Application of a liquid chromatograph coupled with a flameless atomic absorption detector for speciation of trace organometallic compounds, J. Chromatogr. Sci. 15, 493-503 (1977).

5. E. J. Parks, F. E. Brinckman, and W. R. Blair, Application of a graphite furnace atomic absorption detector automatically coupled to HPLC for speciation of metal-containing macromolecules, J. Chromatogr. 185, 563-572 (1979).

6. K. L. Jewett and F. E. Brinckman, Speciation of trace di- and triorganotins in water by ion exchange HPLC-GFAA, J. Chromatogr. Sci. 19, 583-593 (1981).

7. E. J. Parks and F. E. Brinckman, Characterization of bioactive organotin polymers: fractionation and determination of MW by SEC-GFAA, in Controlled Release of Pesticides and Pharmaceuticals, D. H. Lewis, Ed., NY: Plenum Press, 1981, 219-238. 
8. E. J. Parks, R. B. Johannesen, and F. E. Brinckman, Advances in the SEC characterization of organometallic copolymers and copolymerization: Desorption of charged species by injected dilute acetic acid. Nat. Bur. Stand. (U.S.) NBSIR 82-2577; 1982 August, 29 p.

9. M. J. Dempsey, Colonisation of antifouling paints by marine bacteria, Botanica Marina 26, 185 (1981).

10. E. J. Parks, R. B. Johannesen, and F. E. Brinckman, Characterization of organometallic copolymers and copolymerization by size-exclusion chromatography coupled with trace metal- and mass-sensitive detectors, J. Chromatogr. 225, 439 (1983).

11. L. E. Hallas and J. J. Cooney, Tin and tin-resistant microorganisms in the Chesapeake Bay, Appl. and Envir. Micro. $\underline{41}, 446$ (1981).

12. W. P. Iverson and F. E. Brinckman, Microbial metabolism of heavy metals, chapter 8 in Water Pollution Microbiology, Vol. 2, R. Mitchell, Ed., New York, NY: John Wiley \& Sons; 1978, 201-232.

13. A. 0. Summers, S. Silver, Microbial transformations of metals, in Annual Review of Microbiology, Vol. 32, Palo Alto, CA: Annual Reviews, Inc. ; 1978, 637-672.

14. E. J. Parks, R. B. Johannesen, and F. E. Brinckman, unpublished data.

15. R. V. Subramanian and B. K. Garg, Recent advances in organotin polymers, Polym. Plast. Technol. Eng. 11, 81 (1978). 


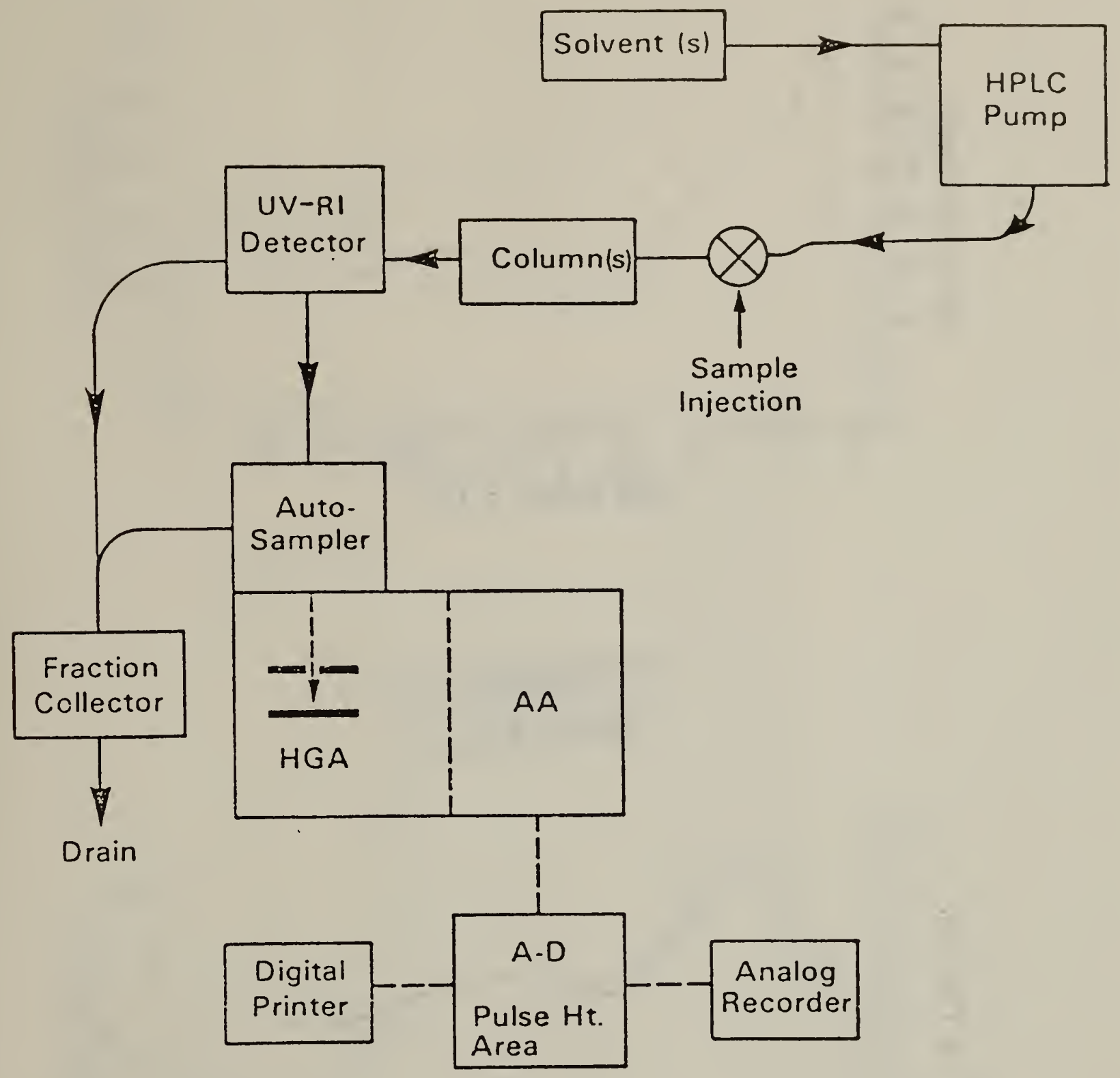

Figure 1. Block diagram summarizing the HFLC-GFAA system, including accessory devices. The GFAA spectrophotometer consists of a heated graphite atomizer (HGA) and an atomic absorption spectrophctometer (AA). In the present work, either the auto-sanpler continuously transferred eluent samples into the graphite furnace at preset intervals, or batch fractions were collected during elution for subsequent quantitation of tin. 


\section{EXPERIMENT 1}

\section{PILING 3-1}

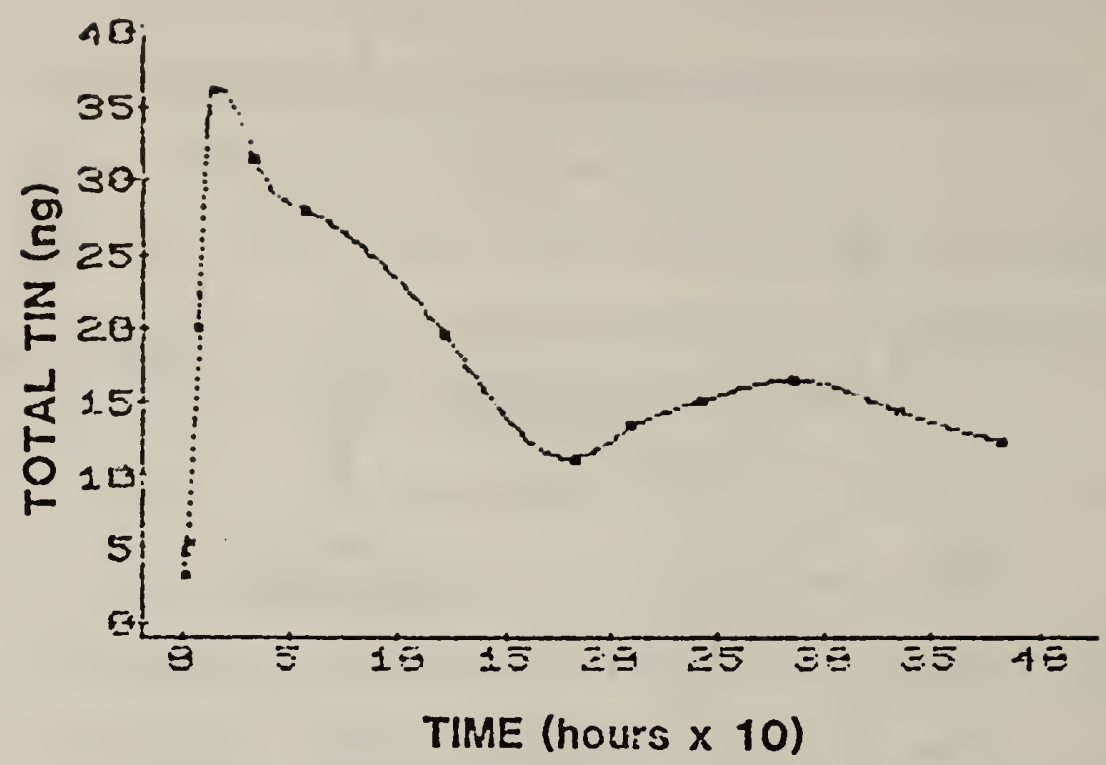

EXPERIMENT 1

PILING 4-5

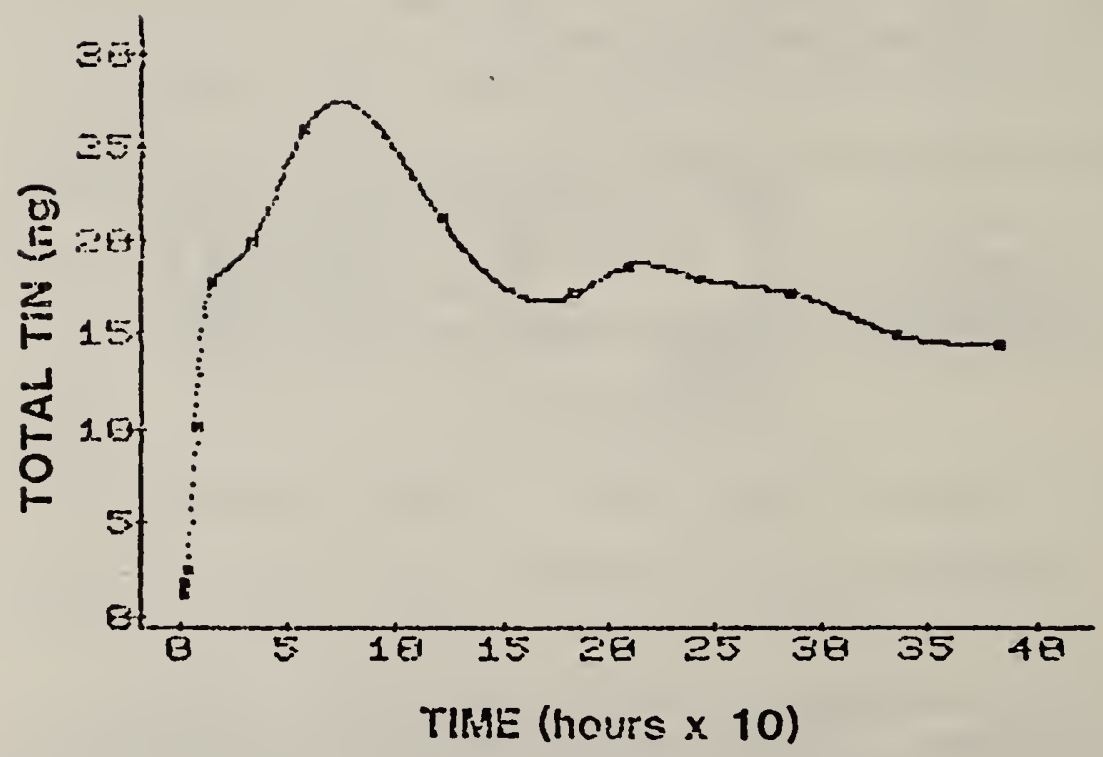

Figure $2 \& 3$. Graphs are constructed by plotting the total tin concentration in the piling leachate water versus time. The data from experiment 1 is plotted above. Both pilings show a relatively rapid initial release of tin, with the concentration reaching a maximum within 2 to $j$ days of the start of the experiment, then declining to a nore stable level as lcaching continued. 


\section{EXPERIIAENT 2}

\section{PILINGG 3-1}

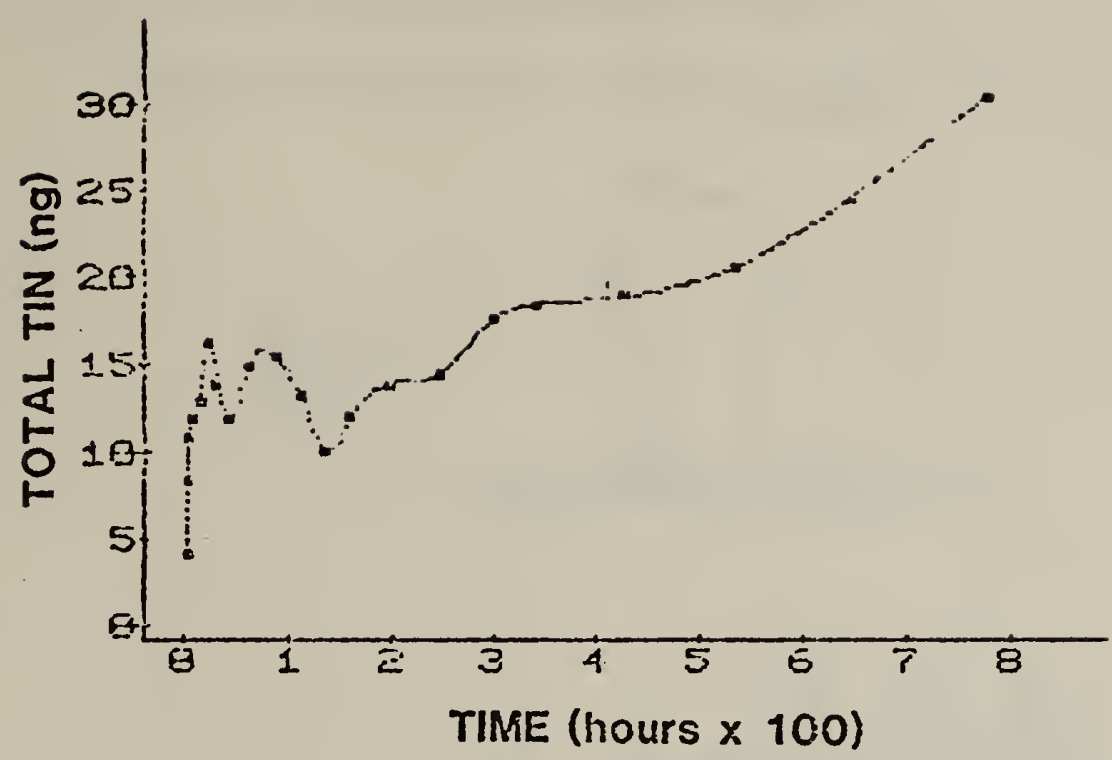

\section{EXPERINENT 2}

PILING $4-5$

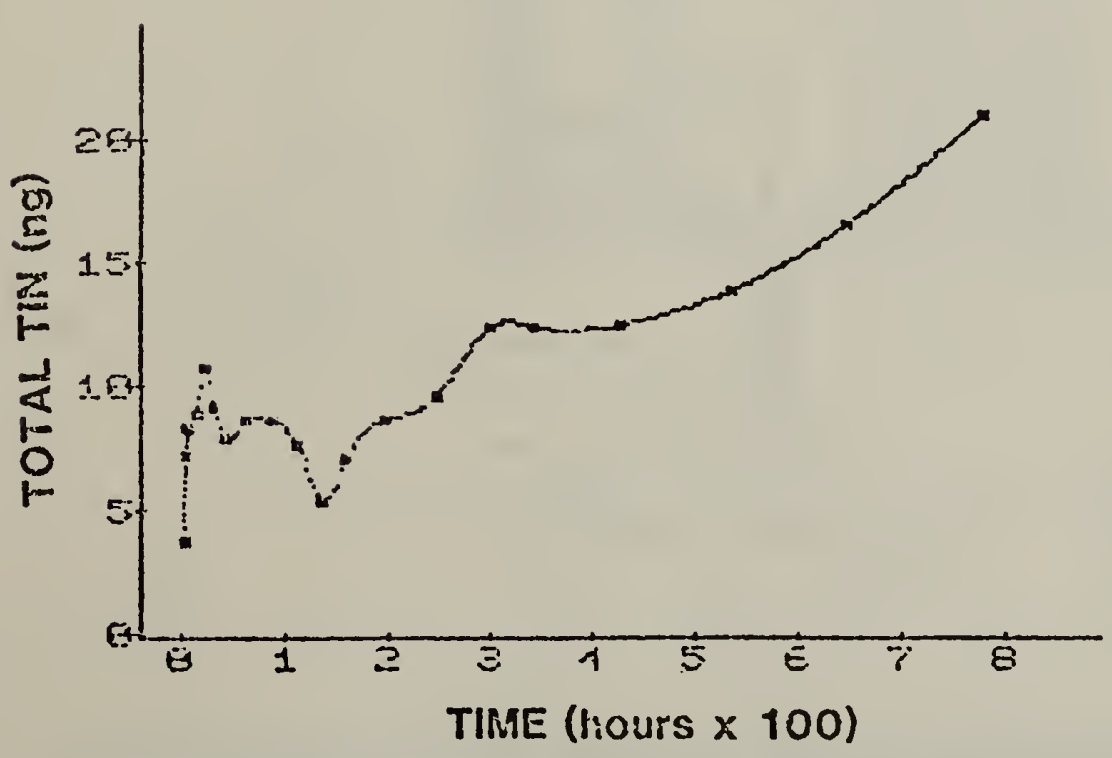

Figure 4 \& 5. Graphs constructed as in figures $2 \& 3$, showing the data from experiment 2. There is considerable variation in the tin levels at the beginning of the experiment, perhaps due to varying rates of water penetration into the pilings and initial surfacc adsorption of tin by the leaching jar. As leaching continued the tin level showed a gradual rise, not unexpected as leached tin was not being removed (cxcept by surface adsorption) from the jars. 

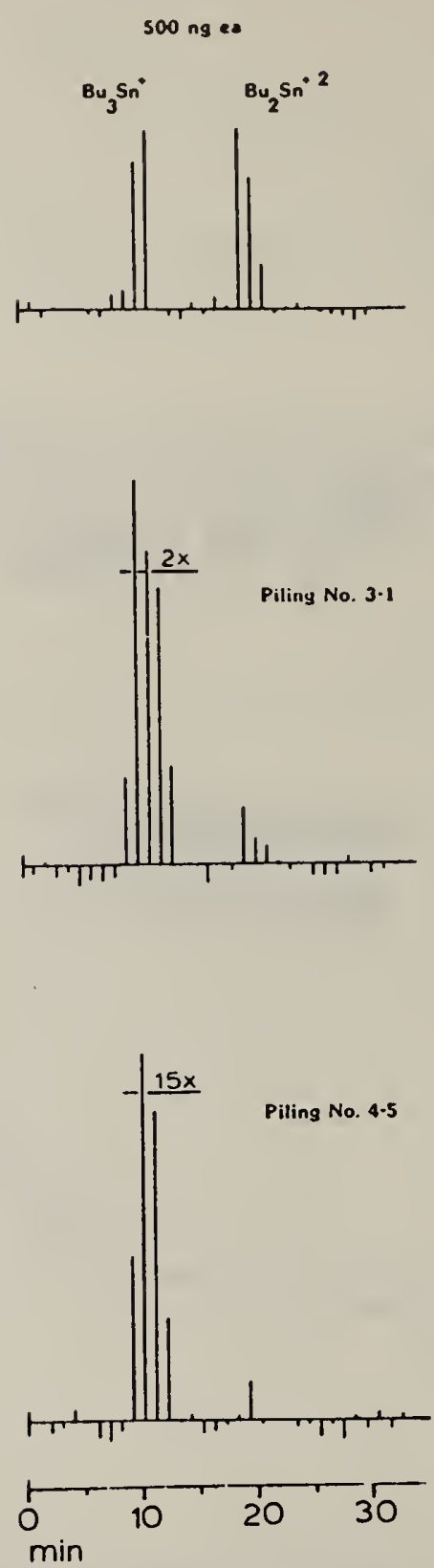

Figure 6. Chromatogram showing GFAA detector responce to 20 microliter sample aliquots withdrawn from the SCX-HPLC eleuent stream. The dibutyitin peak in the chromatogran of piling $3-1$ represents approximately $5.5 \%$ of the total tin in the sample. The dibutyltin peak suggested in the piling 4-5 chromatogran by a single GFAA detector responce represents appruiluatejy $3.4 \%$ cf lít total.tir in the sample. HPLC parameters are listed in table 3 . 


\title{
SIZE EXCLUSION CHROMATOGRAPHY \\ THF EXTRACT OF WOOD PILING NO. 3 - 1
}

\author{
uStyragel $10^{3} \AA$ (one) \\ Solvent THF \\ Eluent THF
}

Multiple delayed injections of $1.0 \%$ HOAC

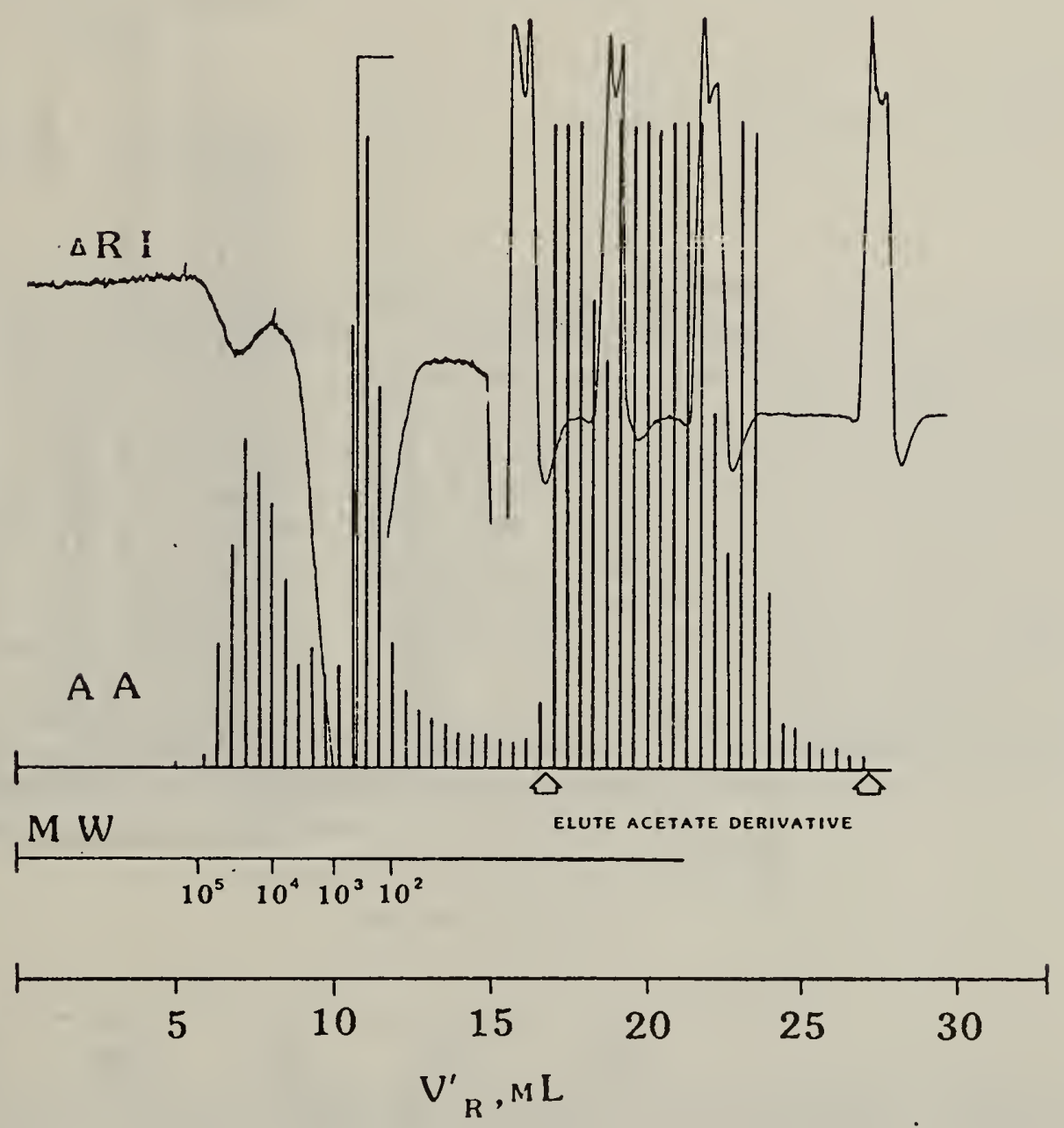

Figure 7. Size exclusion chromatogram of the THF extzact of piling 3-1. Hifg molecular weight (MV) polymer is seen in the $10^{4}$ to $10^{5} \mathrm{MH}$ range. The arrow subtending the $A A$ bascline indicates the point at which a tin-bearing derivative of HOAC begins to elute. Five hundred microliter volumes of $1.0 \%$ ISOAC were injected $10,16,22$ and 33 minutes after the initial sample injection. 


\title{
SIZE EXCLUSION CHROMATOGRAPHY \\ THF EXTRACT OF WOOD PILING NO. $4-5$
}

\author{
HStyragel $10^{3} \AA$ (one) \\ Solvent THF \\ Eluent THF
}

Multiple delayed injections of $1.0 \%$ HOAC

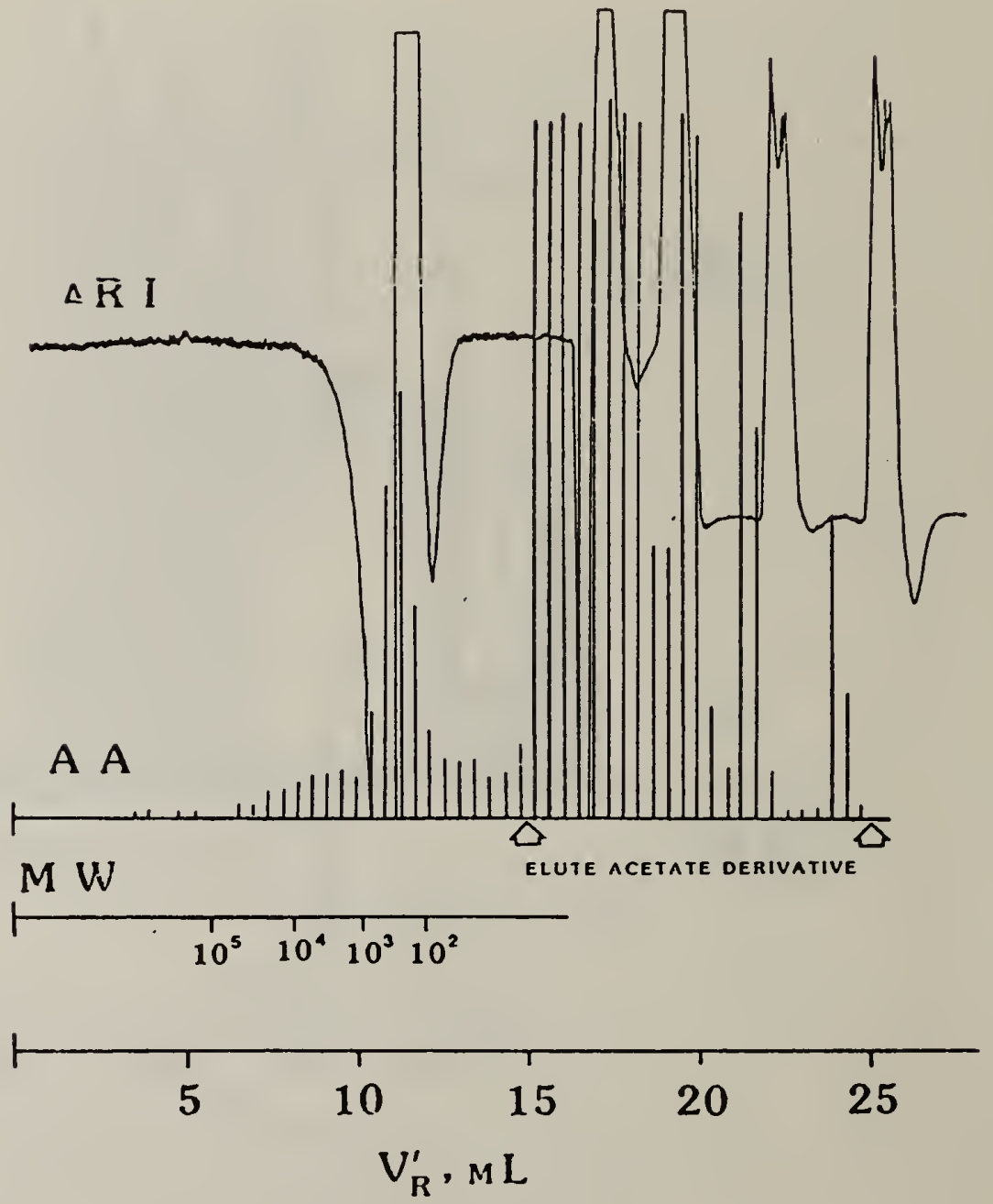

Figure 8. Size exclusion cliromatgrgam of the THF extract of piling 4-5. Note the absence of high MW polymer in comparison to figure 7 . Injections of $1.0 \%$ HOAC followed the sample injection by $8,12,16$, and 20 minutes, with the arrow subtending the $\mathrm{MA}$ baseline indicating the point at which a tin-bearing derivative of HOAC begins to elute. 
NBS-114A (REV. 2-8C)

U.S. DEPT. OF COMM.

BIBLIOGRAPHIC DATA

SHEET (See instructions)

1. PUBLICATION OR REPORT NO.

NBSIR $83-2733$

4. TITLE AND SUBTITLE

Characterization of Leaching Dynamics and Identification of Leached Species from OMP Impregnated Wood Pilings

5. $\operatorname{AUTHOR}(\mathrm{S})$

W.R.Blair, E.J.Parks, and F.E.Brinckman

6. PERFORMING ORGANIZATION (If joint or other than NBS, see instructions)

NATIONAL BUREAU OF STANDARDS

DEPARTMENT OF COMMERCE

WASHINGTON, D.C. 20234

7. Contract/Grant No. N68305 82MP20019

8. Type of Report \& Period Covered final

9. SPONSORING ORGANIZATION NAME AND COMPLETE ADDRESS (Street, City, State, ZIP)

Naval Civil Engineering Laboratory

Port Hueneme, CA 93043

10. SUPPLEMENTARY NOTES

Document describes a computer program; SF-185, FIPS Software Summary, is attached.

11. ABSTRACT (A 200-word or less foctual summary of most significant information. If document includes a significant bibliogrophy or literoture survey. mention it here)

Organometallic polymers (omp) are becoming an increasingly important class

of compounds finding application in marine environments as anti-fouling and preservative agents. To provide accurate estimates of reliability in service and service life, new analytical methods are needed for the identification and measurement of the toxic species being delivered by the OMP. This report is concerned with the following: identification of parent tin species; identification of species leached from OMP impregnated wood pilings; and preliminary determination of the rate of tin release from OMP impregnated pilings. Additionally, the influence of microbiological activities on the leachate is considered in assessing the effectiveness and ultimate fate of the toxic species responsible for the anti-fouling and preservative properties of the OMP formulation. Data from leach rate measurment experiments are presented, along with chromatograms providing speciation data on parent and leachate tin compounds, discussion of areas for continued research are presented.

12. KEY WORDS (Six to twelve entries; alphabetical order; capitalize only proper names; and separate key words by semicolons) atomic absorption spectrophotometry; cation exchange chromatography; high pressure liquid chromatography; in situ polymerization; leaching; organometallic polymers; size exclusion chromatography; tributyltin

13. AVAILABILITY

[XX Unlimited

For Official Distribution. Do Not Release to NTIS

Order From Superintendent of Documents, U.S. Government Printing Office, Washington, D.C. 20402.

XX] Order From National Technical Information Service (NTIS), Springfield, VA. 22161

14. NO. OF

PRINTED PAGES

\section{8}

15. Price

$\$ 8.50$ 


